Banco, Volume 1, Mei 2019

\title{
IMPLEMENTASI AKAD MURABAHAH PADA PEMBIAYAAN KPR DI BANK TABUNGAN NEGARA SYARIAH PAREPARE
}

\author{
Fitri Handayani \\ Staff Administrasi DPRD Kota Parepare \\ fitrihandayani@yahoo.com \\ Rahman Ambo Masse \\ IAIN Parepare \\ rahmanambomasse@iainpare.ac.id \\ Sunuwati \\ IAIN Parepare \\ sunuwati@iainpare.ac.id
}

\section{Abstract}

This study discusses the implementation of murabahah contracts on mortgage financing in the Parepare Islamic state savings bank. That the BTN Syariah bank is a unit of conventional Bank BTN which raises doubts about mortgage financing, whether or not it has implemented murabahah contracts in mortgage financing or not. As recommended by the DSN fatwa and Indonesian banks. This study aims to determine the implementation of the murabahah contract on mortgage financing at the Parepare Syariah State Savings Bank.

The results of this study indicate that: (1) the financing mechanism for mortgages at Bank BTN Syariah Parepare is in accordance with the rules of banks and government, the rules governed by the government are the rules regarding subsidized mortgages stipulated in PermenPUPR Number 21 / PRT / M / 2016 concerning convenience and or assistance in obtaining houses for low income people. PermenPUPR Number 26 / PRT / M / 2016 concerning changes to the ministerial regulations on public works and public housing number 21 / PRT / M / 2016 and PermenPUPR Republic of Indonesia Number 425 / KPTS / M / 2015 concerning limits on house selling prices that can be obtained through credit or financing of prosperous home ownership. (2) Implementation of murabahah 
contract at BTN Syariah Parepare bank, terms and conditions are in accordance with the principle of murabahah contract, murabahah contract has not implemented well on mortgage products at BTN Syariah Parepare bank due to the existence of murabahah contract elements which are not in accordance with the fatwa of the board national shariaMUI. The element of the murabahah contract that is not in accordance with the DSN-MUI fatwa is the down payment and rescheduling. The elements of the murabahah contract are in accordance with the DSN-MUI fatwa, namely discounts, settlement of accounts receivable, fines and accelerated repayments.

Keywords: Akad murabahah, pembiayaan, KPR

\section{Abstrak}

Penelitian ini membahas mengenai implementasi akad murabahah pada pembiayaan KPR di bank tabungan negara syariah Parepare. Bahwa bank BTN Syariah Merupakan unit dari Bank BTN konvensional sehingga menimbulkan keraguan pada pembiayaan KPR, apakah sudah menerapkan akad murabahah dalam pembiayaan KPR atau belum. Sebagaimana rekomendasi fatwa DSN dan bank Indonesia. Penelitian ini bertujuan untuk Mengetahui implementasi akad murabahah pada pembiayaan KPR pada Bank Tabungan Negara Syariah Parepare.Hasil penelitian ini menunjukkan bahwa: (1) Mekanisme pembiayaan KPR pada bank BTN Syariah Parepare sudah sesuai dengan aturan bank dan pemerintah, aturan yang diatur oleh pemerintah yaitu aturan mengenai KPR subsidi yang diatur dalam permenPUPR Nomor 21/PRT/M/2016 tentang kemudahan dan atau bantuan perolehan rumah bagi masyarakat berpenghasilan rendah. permenPUPR Nomor 26/PRT/M/2016 tentang perubahan atas peraturan menteri pekerjaan umum dan perumahan rakyat nomor 21/PRT/M/2016 dan permenPUPR Republik Indonesia Nomor 425/KPTS/M/2015 tentang batasan harga jual rumah yang dapat diperoleh melalui kredit atau pembiayaan pemilikan rumah sejahtera. (2) Implemetasi akad murabahah pada bank BTN Syariah Parepare, syarat dan rukun sudah sesuai dengan prinsip akad murabahah, akad murabahah belum berimplemetasi dengan baik pada produk KPR di bank BTN Syariah Parepare dikarenakan masih adanya unsur-unsur akad murabahah yang tidak sesuai dengan fatwa dewan syariah nasional-MUI. Unsur akad murabahah yang tidak sesuai dengan fatwa DSNMUI yaitu uang muka dan penjadwalan kembali. Adapun unsur akad murabahah yang sudah sesuai dengan fatwa DSN-MUI yaitu diskon, penyelesaian piutang, denda, dan potongan pelunasan dipercepat.

\section{Kata Kunci : Akad murabahah, pembiayaan, KPR}

\section{A. Pendahuluan}

Lembaga keuangan di Indonesia telah berkembang dimana ada dua bentuk lembaga keuangan yaitu syariah dan konvensional. Hal ini menyebabkan banyak pihak ingin mengetahui apa perbedaan yang mendasar antara lembaga keuangan syariah dengan lembaga keuangan konvensional, perbedaann lembaga keuangan syariah dan konvensional terletak pada akad atau transaksinya. Pada lembaga keuangan syariah khususnya bank syariah.

Perbankan syariah berfungsi halnya perbankan lainnya, lembaga intermediary yang berfungsi mengumpulkan dana dan menyalurkannya kepada masyarakat dalam bentuk 
pemberian fasilitas pembiayaan. Bank Syariah adalah lembaga keuangan yang usaha pokoknya memberikan pembiayaan dan jasa-jasa lainya dalam lalu lintas pembayaran serta peredaran uang yang pengoperasiannya disesuaikan dengan prinsip syariat Islam. ${ }^{1}$

Awal berdirinya Bank Syariah di Indonesia didasarkan Undang-Undang No. 7 tahun 1992, kemudian direvisi dengan Undang-Undang No. 10 tahun 1998 tentang perbankan. UndangUndang tersebut mengakomodir bank yang beroperasinya dengan sistem bagi hasil atau bank syariah. ${ }^{2} \quad$ Pengertian bank menurut Undang-Undang No. 10 tahun 1998 tentang perubahan atas Undang-Undang No. 7 tahun 1992 tentang perbankan adalah badan usaha yang menghimpun dana dari masyarakat dalam bentuk simpanan dan menyalurkannya kepada masyarakat dalam bentuk kredit dan atau bentuk-bentuk lainnya dalam rangka meningkatkan taraf hidup rakyat banyak. ${ }^{3}$

Sedangkan menurut UU No. 21 Tahun 2008 adalah badan usaha yang menghimpun dana masyarakat dalam bentuk simpanan dan menyalurkanya kepada masyarakat dalam bentuk kredit dan atau bentuk-bentuk lainnya dalam rangka meningkatkan taraf hidup rakyat banyak. ${ }^{4}$ Pembiayaan berdasarkan prinsip syariah adalah penyediaan uang atau tagihan yang dipersamakan dengan itu berdasarkan persetujuan atau kesepakatan pinjam meminjam antara bank dengan pihak lain yang mewajibkan pihak yang dibiayai untuk mengembalikan $u$ ang atau tagihan tersebut setelah jangka waktu tertentu dengan imbalan atau bagi hasil.

Pembiayaan pada Bank Syariah ditempuh melalui mekanisme jual beli, sewa, dan invenstasi. Implementasi akad jual beli merupakan salah satu cara yang ditempuh bank syariah dalam rangka menyalurkan dana kepada masyarakat. Akad bank yang didasarkan pada akad jual beli adalah murabahah, salam, dan istishna>. Salah satu bentuk pembiayaan jual beli adalah murabahah. Murabahah yaitu jual beli barang pada harga asal dengan tambahan keuntungan yang disepakati. Dalam murabahah, Penjual harus memberi tahu harga produk yang ia beli dan menentukan suatu tingkat keuntungan sebagai tambahannya. ${ }^{5}$

Perbankan Syariah pada umumnya menggunakan Murabahah sebagai metode utama pembiayaan, porsi pembiayaan dengan akad murabahah saat ini berkontribusi $58 \%$ dari total

${ }^{1}$ Muhammad. Manajemen Bank Syariah, Edisi Revisi (Yogyakarta: UPP AMP YKPN, 2005), h. 13.

${ }^{2}$ Muhammad, Manajemen Bank Syariab. h.14.

${ }^{3}$ Alfitra, Modus Operandi Pidana Khusus Di Luar KUHP (Jakarta: Raih Asa Sukses, 2014), h. 68.

${ }^{4}$ Ikit, Akutansi Penghimpunan Dana Bank Syariah (Yogyakarta: Deepublish, 2015), h. 44.

${ }^{5}$ Muhammad Syafi'i Antonio, Bank Syari'ab; Dari Teori ke Praktik, (Jakarta: Gema Insan, 2001), h. 101.

Banco, Volume 1, Mei 2019 
pembiayaan perbankan syariah di Indonesia. ${ }^{6}$ Rumah merupakan kebutuhan dasar manusia, sebagai kebutuhan utama manusia maka rumah diminati banyak orang. Namun harga rumah yang melambung tinggi menyebabkan jarang orang mampu membeli rumah secara tunai, sehingga membeli dengan angsuran atau menyewa adalah alternatif yang dipilih. Dari hasil survey harga properti resindesial triwulan III-2017 Bank Indonesia, mengatakan bahwa sebagian besar konsumen $(76,42 \%)$ masih memilih kredit kepemilikan rumah (KPR) sebagai fasilitas utama dalam melakukan transaksi pembelian property resindensial. Sementara itu proporsi konsumen memilih skema pembayaran tunai bertahap sebesar 17,13\% dan secara tunai $6,45 \% .^{7}$ Hal ini mengindikasikan bahwa pembelian rumah secara angsuran lebih banyak dibandingkan secara tunai.

Banyak cara yang dapat ditempuh oleh masyarakat dalam memenuhi kebutuhan pokok mereka dalam hal perumahan. Disinilah bank muncul menjembatani kepentingan pembeli dan penjual rumah dengan menawarkan produk murabahah yaitu pembiaayan KPR Syariah. Pembiayaan KPR Syariah memiliki kelebihan dibandingkan konvensional yaitu angsuran tetap sampai akhir pembayaran. Beragam bank menawarkan fasilitas KPR Syariah, salah satunya bank Tabungan Negara Syariah. Bank Tabungan Negara Syariah merupakan lembaga keuangan yang berprinsip Islam. Bank Tabungan Negara Syariah berdiri pada 14 februari 2005.8

Bank Tabungan Negara Syariah (BTN Syariah) Parepare menawarkan produk KPR yaitu yang bernama KPR BTN iB. Bank milik pemerintah ini mempunyai layanan kredit KPR BTN iB yaitu suatu fasilitas kredit dalam rangka nasabah membeli rumah dengan cara diangsur atau dicicil dalam jangka waktu tertentu. ${ }^{9}$

Kenyataanya bahwa bank BTN Syariah Merupakan unit dari Bank BTN konvensional sehingga menimbulkan keraguan pada pembiayaan KPR, apakah sudah menerapkan akad murabahah dalam pembiayaan KPR atau belum?. Sebagaimana rekomendasi fatwa DSN dan Bank Indonesia. Karena itu, penelitian ini terasa urgent untuk dilakukan dengan pokok masalah Bagaimana implementasi akad murabahah pada pembiayaan KPR di Bank Tabungan Negara Syariah Parepare?, yang dirinci dengan sub masalah sebagai berikut.

\section{B. Diskusi dan Pembahasan}

6 Otoritas Jasa Keuangan, "Buku Standar Produk Perbankan Syariah Murabahah", Situs Resmi Otoritas Jasa Keuangan. http:/ / www.ojk.go.id (16 Januari 2018).

7Bank Indonesia, "Survei Harga Properti Residensial,Triwulan III-2017", Situs Resmi Bank Indonesia. http://www.bi.go.id/ (16 Januari 2018)

${ }^{8}$ BTN Syariah,"Profil BTN Syariah”, Situs Resmi BTN Syariah. http://www.btn.co.id/ ( 2017).

'BTN Syariah, "Produk". Situs Resmi BTN Syariah. http://www.btn.co.id/ (10 Juli 2017). 


\section{Mekanisme Pembiayaan KPR Pada Bank BTN Syariah Parepare}

\section{Produk Pembiayaan Murabahah pada KPR di Bank BTN Syariah Parepare}

Bank syariah adalah bank yang menjalankan usahanya bedasarkan pada prinsip syariah, pada pelaksaan perbankan syariah menawarkan tiga produk yaitu produk pendanaan, pembiayaan, dan jasa, adapun produk-produk tersebut yang ditawarkan oleh bank BTN syariah yaitu sebagai berikut:

a. Produk Pendanaan

1) Tabungan, terdiri atas:

a) BTN Batara iB

Produk tabungan dengan menggunakan akad "Wadiab" (Titipan), yang merupakan titipan dari satu pihak ke pihak lain baik individu maupun lembaga yang harus dijaga dan dikembalikan setiap saat bila pemilik menghendakinya.

b) BTN Prima iB

Produk tabungan dengan menggunakan akad "Mudharabah Mutlaqah (investasi)", yang merupakan kerja sama antara dua pihak. Pihak pertama (shabibul maal) menyediakan modal dan memberikan kewenangan penuh kepada pihak lainnya (mudharib) dalam menentukan jenis dan tempat investasi. Keuntungan dan kerugian dibagi menurut nisbah yang disepakati dimuka.

c) BTN Batara Haji \& Umroh iB

Produk tabungan untuk merencanakan ibadah haji dan umroh berdasarkan prinsip syariah dengan menggunakan akad "Mudharabah Mutlaqah" (investasi), yang merupakan kerja sama antara dua pihak dengan keuntungan dan kerugian dibagi menurut nisbah yang disepakati dimuka.

d) Tabungan BTN Qurban iB

Produk tabungan untuk merencanakan pembelian dan penyaluran hewan qurban dengan bagi hasil yang menguntungkan dan kompetitif berdasarkan prinsip syariah dengan akad "Mudharabah Mutlaqah" (investasi), yang merupakan kerja sama antara dua pihak dengan keuntungan dan kerugian dibagi menurut nisbah yang disepakati dimuka.

e) BTN Tabunganku iB

Produk tabungan untuk merencanakan pembelian dan penyaluran hewan qurban dengan bagi hasil yang menguntungkan dan kompetitif berdasarkan prinsip syariah dengan akad "Mudharabah Mutlaqab" (Investasi), yang merupakan kerja sama antara dua pihak dengan keuntungan dan kerugian dibagi menurut nisbah yang disepakati dimuka.

f) BTN Simpanan Pelajar iB

Tabungan untuk meningkatkan budaya menabung di kalangan siswa PAUD, TK, SD, SMP, SMA, Madrasah (MI, MTs, MA) atau sederajat dengan prinsip syariah yaitu akad "Wadiab" (Titipan), dimana merupakan titipan dari satu pihak ke pihak lain baik individu maupun lembaga yang harus dijaga dan dikembalikan setiap saat bila pemilik menghendakinya. 


\section{g) BTN Emas iB}

Produk tabungan untuk merencanakan pembelian emas yang merupakan salah satu bentuk investasi terbaik guna memenuhi kebutuhan masa depan dengan tetap mendapatkan bagi hasil yang menguntungkan serta berdasarkan prinsip syariah dengan akad "Mudharabah Mutlaqab" (Investasi)", yaitu kerja sama antara dua pihak dengan keuntungan dan kerugian dibagi menurut nisbah yang disepakati dimuka.

2) Deposito

a) Deposito BTN iB

Investasi berjangka bagi perorangan atau lembaga dengan bagi hasil kompetitif yang menggunakan akad "Mudharabah Mutlaqah" (Investasi), yaitu kerja sama antara dua pihak dengan keuntungan dan kerugian dibagi menurut nisbah yang disepakati dimuka.

b) Deposito On Call BTN iB

Investasi berjangka yang dapat memberikan optimalisasi keuntungan bagi likuiditas perusahaan dengan jangka waktu 1-28 hari dan dikelola melalui akad "Mudharabah Mutlaqah" (Investasi), yang merupakan kerja sama antara dua pihak dengan keuntungan dan kerugian dibagi menurut nisbah yang disepakati dimuka.

\section{3) Giro}

a) Giro BTN iB

Investasi berjangka yang dapat memberikan optimalisasi keuntungan bagi likuiditas perusahaan dengan jangka waktu 1-28 hari dan dikelola melalui akad "Mudharabah Mutlaqab" (Investasi), yang merupakan kerja sama antara dua pihak dengan keuntungan dan kerugian dibagi menurut nisbah yang disepakati dimuka.

b) Giro BTN Prima iB

Produk simpanan dengan bagi hasil yang kompetitif untuk perusahaan yang memiliki aktifitas transaksi bisnis yang tinggi dengan menggunakan Akad "Mudharabah Mutlaqab" (Investasi), yang merupakan kerja sama antara dua pihak dengan keuntungan dan kerugian dibagi menurut nisbah yang disepakati dimuka.

b. Produk Pembiayaan

1) Pembiayaan Bangunan

a) KPR BTN Platinum iB

Pembiayaan yang hadir sebagai solusi bagi kepemilikan rumah, ruko, hingga apartemen yang menjadi idaman, baik untuk pertama kali, yang kedua, atau bahkan yang ketiga melalui proses yang cepat, uang muka ringan dan angsuran tetap selama jangka waktu pembiayaan melalui akad "Murabahab" (jual beli) yang memberikan berbagai macam manfaat

b) KPR BTN Indent iB 
Fasilitas pembiayaan untuk memiliki rumah, ruko, rukan, rusun atau apartemen berdasarkan pesanan melalui akad "Istishna >" (jual beli berdasarkan pesanan)

c) Pembiayaan Bangun Rumah BTN iB

Pembiayaan yang dapat mewujudkan pembangunan rumah impian atau merenovasi hunian diatas lahan milik sendiri sesuai rencana dan keinginan nasabah melalui akad "Murabahah" (jual beli)

d) Pembiayaan Properti BTN iB

Pembiayaan untuk masyarakat yang menginginkan kepemilikan atas properti baru atau memerlukan pembiayaan ulang (refinancing) untuk properti yang telah dimiliki dengan menggunakan akad "musyarakah mutanaqisah" (kepemilikan asset bersama)

e) KPR BTN Bersubsidi iB

Pembiayaan yang ditujukan untuk program kesejahteraan masyarakat berpenghasilan rendah yang bekerjasama dengan Kementerian Pekerjaan Umum dan Perumahan Rakyat dalam rangka kemudahan kepemilikan rumah, dengan akad "Murabahah" (jual beli) yang memberikan berbagai macam manfaat

2) Pembiayaan Ringan

a) Pembiayaan kendaraan bermotor iB

Solusi kepemilikan kendaraan roda dua atau roda empat dengan proses yang cepat, administrasi yang mudah, harga dan angsuran yang tetap sampai dengan akhir pembiayaan melalui akad Murabahah (Jual Beli).

b) Pembiayaan tunai emas BTN iB

Solusi atas kebutuhan dana untuk keperluan mendadak dengan cara menggadaikan emas yang dimiliki dengan proses yang cepat dan aman serta angsuran yang ringan menggunakan akad "Qardh" (gadai) yang disertai dengan surat gadai sebagai penyerahan Marhun untuk jaminan pengembalian seluruh atau sebagian hutang nasabah kepada bank (Murtabin).

c) Pembiayaan emasku BTN ib

Pembiayaan Emasku BTN iB hadir untuk memberikan solusi bagi nasabah yang ingin memiliki investasi dengan kepemilikan emas lantakan (batangan) bersertifikat Antam berdasarkan prinsip syariah dengan menggunakan akad Murabahah (Jual Beli).

d) Pembiayaan multimanfaat BTN iB

Solusi bagi pegawai dan pensiunan untuk keperluan pembelian jenis barang elektronik, furniture, dan kebutuhan lainnya tanpa uang muka, angsuran ringan dan tetap sampai dengan lunas dan jangka waktu pembiyaan sampai dengan 10 tahun melalui akad "Murababab" (Jual Beli)

e) Pembiayaan multijasa BTN iB

Pembiayaan yang hadir untuk keperluaan mendanai kebutuhan layanan jasa seperti Pendidikan, Kesehatan, Wisata, Umroh, dan Pernikahan dengan jangka 
waktu pembiayaan sampai dengan 10 tahun serta menggunakan akad "Kafalah bil Ujrob" (Imbalan atas jasa penjaminan).

f) Pembiayaan Usaha

- Pembiayaan kontruksi BTN iB

Pembiayaan Konstruksi BTN iB hadir untuk memberikan solusi bagi pebisnis guna membiayai konstruksi proyek properti yang meliputi bangunan dan infrastruktur yang terkait dengan menggunakan akad "Musyarakah" (kerjasama)

- Pembiayaan Investasi BTN iB

Pembiayaan Investasi BTN iB hadir untuk memberikan solusi bagi nasabah guna pembelian/pengadaan barang investasi (capital expenditure) dengan menggunakan akad akad "Murabahab" (penyediaan dana atau tagihan), "Musyarakah" (akad penyediaan dana untuk kerja sama) atau "Istishna>" (akad penyediaan dana atau tagihan).

g) Pembiayaan Modal Kerja BTN iB

Pembiayaan Modal Kerja BTN iB hadir untuk memberikan solusi bagi nasabah guna membiayai keperluan modal kerja nasabah (operational expenditure) dalam menjalankan bisnis dengan menggunakan akad kerjasama (mudharabah atau musyarakah).

c. Jasa dan Layanan

1) Jasa penyimpanan

a) Safe deposit box

Suatu wadah dalam bentuk box yang dirancang khusus dengan ukuran tertentu dan dilengkapi dengan sistem pengamanan untuk menjamin keamanan barang-barang yang disimpan dari bahaya kebakaran, perampokan dan lain-lain serta menggunakan akad $i j a>$ rah (sewa menyewa).

2) Layanan

a) Program Pengembangan Operasional (PPO)

Layanan perbankan untuk korporasi dengan memfasilitasi kebutuhan operasional berupa barang (seperti kendaraan, peralatan kantor, dan lain-lain) ataupun dana operasional dalam rangka mendukung kelancaran operasional lembaga dengan persyaratan tertentu yang disepakati bank dan nasabah.

b) Penerimaan biaya perjalanan haji

Layanan untuk mempermudah impian ibadah haji ke Tanah Suci yang terintegrasi langsung dengan sistem komputerisasi haji terpadu online, mulai dari pembayaran setoran awal untuk mendapatkan nomor porsi sampai dengan pelunasan keberangkatan.

c) BTN Payroll

Layanan perbankan melalui Tabungan BTN Batara iB untuk memfasilitasi jasa payroll dan kebutuhan finansial karyawan korporasi yang dapat dilakukan diseluruh outlet 
Bank BTN ataupun UUS Bank BTN diseluruh wilayah Indonesia.

d) SPP online

Merupakan jasa layanan bagi lembaga pendidikan berupa penerimaan setoran biaya pendidikan dan biaya lainnya yang terkait dengan penyelenggaraan pendidikan secara online real time.

e) Payment Point BTN iB

Layanan perbankan untuk kemudahan nasabah melakukan transaksi berulang dan rutin seperti membayar tagihan rutin seperti tagihan telepon, telepon seluler, listrik, air, dan pajak.

Dari 6 produk pembiayaan akad murabahah pada bank BTN syariah ada 2 produk yang merupakan produk pembiayaan kepemilikan rumah. Adapun produk tersebut yaitu :

a) KPR BTN Platinum iB

Pembiayaan yang hadir sebagai solusi bagi kepemilikan rumah, ruko, hingga apartemen yang menjadi idaman, baik untuk pertama kali, yang kedua, atau bahkan yang ketiga melalui proses yang cepat, uang muka ringan dan angsuran tetap selama jangka waktu pembiayaan melalui akad "Murababab" (jual beli) yang memberikan berbagai macam manfaat.

Produk KPR BTN platinum ib merupakan produk pembiayaan non subsidi atau reguler yang besaran marginnya ditentukan oleh kebijakan bank.

b) KPR BTN Bersubsidi iB

Pembiayaan yang ditujukan untuk program kesejahteraan masyarakat berpenghasilan rendah yang bekerjasama dengan Kementerian Pekerjaan Umum dan Perumahan Rakyat dalam rangka kemudahan kepemilikan rumah, dengan akad "Murabahab" (jual beli) yang memberikan berbagai macam manfaat.

Produk KPR BTN bersubsidi iB merupakan produk pembiayaan kepemilikan rumah yang di bantu oleh pemerintah yang ditujukan kepada masyarakat yang berpenghasilan rendah atau menengah kebawah, adapun salah satu bentuk bantuan pemerintah yang diberikan yaitu uang muka sebesar Rp. 4.000.000,- yang biasa disebut SBUM (subsidi bantuan uang muka).

- $\quad$ Kategori pemberian KPR bersubsidi yaitu :

○ Memiliki KTP

○ Tidak memiliki rumah

- Belum pernah menerima subsidi perolehan rumah berupa kepemilikan rumah dari pemerintah

- Memiliki nomor pokok wajib pajak (NPWP)

- Memiliki SPT tahunan $\mathrm{PPh}$ orang pribadi sesuai peraturan perundang undangan

- Memiliki penghasilan tidak melebihi batas penghasilan yang dibuktikan slip 
gaji yang disahkan oleh pejabat yang berwenang atau surat pernyataan penghasilan dari yang bersangkutan untuk penghasilan tidak tetap yang diketahui oleh kepala desa/lurah tempat KTP diterbitkan. ${ }^{10}$

Hal ini sesuai dengan yang dijelaskan oleh saudara Andi Habrianto selaku financing service yang mengatakan.

"pemberian KPR bersubsidi hanya diberikan kepada masyarakat yang berpenghasilan gaji pokok dibawah Rp. 4.000.000,-, belum memiliki rumah dan tidak pernah menerima KPR bersubsidi”. ${ }^{11}$

- Keunggulan Produk Pembiayaan KPR BTN Syariah Parepare

- Angsuran tetap sampai lunas

- Bebas finalty

- Margin bersaing

- Proses cepat dengan layananan unggul

- Jangka waktu sampai dengan 20 tahun $^{12}$

- Syarat dan Ketentuan Pengajuan Pembiayaan

- Warga Negara Indonesia (WNI)

- Usia minimal 21 tahun atau telah menikah

- Pada saat pembiayaan lunas usia tidak lebih dari 65 tahun

- Minimum masa kerjausaha 1 (satu) tahun

- Tidak memiliki kredit atau pembiayaan bermasalah (IDI BI clear)

- Memiliki NPWP atau SPT Psl 21

- Syarat Dokumen

- Kelengkapan data formulir aplikasi

- Foto pemohon atau pasangan ukuran $3 \times 4$ ( 1 Lembar )

- Photo copy KTP pemohon

- Photo copy KTP pasangan (apabila status pemohon telah menikah)

- Photo copy NPWP pemohon ( untuk pembiayaan diatas 100 juta ) / SPT (50-100 juta)

${ }^{10}$ Menteri Pekerjaan Umum dan Perumahan Rakyat, permenPUPR nomor 26/ PRT/M/ 2016 tentang perubahan atas peraturan menteripekerjaan umum dan perumaban rakyat nomor 21/PRT/M/2016 tentang kemudaban dan / atau bantuan perolehan rumah bagi masyarakat berpenghasilan rendah.

11 Andi Habriantho, Financing Service, wawancara oleh Peneliti di Bank BTN Syariah Parepare, 2 Mei 2018

12 Dokumen PT. Bank Tabungan Negara (persero), Tbk. kantor cabang pembantu syariah Parepare Pada tanggal 2 mei 2018 
- Photo copy akta nikah atau akta cerai atau surat keterangan belum nikah dari kelurahan

- Photo copy kartu keluarga

- Rekening koran pemohon, 3 bulan terakhir (pemohon atau pasangan)

- Surat keterangan belum memiliki rumah dari kelurahan atau desa.

- Biaya-biaya terkait pembiayaan KPR BTN Syariah

- Biaya administrasi

- Biaya proses

- Notaris

- Premi asuransi jiwa

- Premi asuransi kebakaran

- SKMHT (Surat kuasa membebankan hak tanggungan)

- APHT (Akta pemberian hak tanggungan)

- Appraiser

- Angsuran bulan terakhir (untuk diblokir 1 kali angsuran)

- Setoran minimum ${ }^{13}$

\section{Implementasi Akad Murabahah Pada Bank BTN Syariah Parepare}

Implemetasi adalah sebuah tindakan yang dilakukan baik secara individu maupun kelompok dengan maksud untuk mencapai tujuan yang telah dirumuskan.

Adapun unsur implementasi yaitu:

a. Adanya program yang dilaksanakan

b. Adanya kelompok target yaitu masyarakat yang menjadi sasaran dan diharapkan akan menerima manfaat dari program tersebut

c. Adanya pelaksanaan sebuah hasil kerja yang diperoleh melalui sebuah cara agar dapat dipraktekan kedalam masyarakat

Program akad Murabahah ini dilaksanakan pada produk pembiayaan, salah satunya yaitu produk pembiayaan rumah, yang pada bank BTN Syariah produk tersebut itu adalah KPR BTN Platinum iB dan KPR BTN bersubsidi iB.

Untuk melihat Implementasi akad murabahah pada KPR dapat di lihat di kontrak atau akad atau biasa disebut dengan PK (perjanjian kredit), PK tersebut merupakan bukti pemberian pembiayaan kepada nasabah yang berisi dengan klausul-klausul. Yang dimana apabila kemudian hari terjadi perselisihan antara bank dan nasabah maka PK tersebut akan menjadi bukti bagi bank dan nasabah.

a. Struktur Akad Pembiayaan murabahah

1) Judul akad

2) Kedudukan pihak yang berakad

13 Dokumen PT. Bank Tabungan Negara (persero) Tbk. kantor cabang pembantu syariah Parepare. Pada tanggal 2 mei 2018.

Banco, Volume 1, Mei 2019 
3) Isi Akad

\begin{tabular}{|c|c|}
\hline PK Platinum & PK Subsidi \\
\hline ketentuan pokok akad & ketentuan pokok akad \\
\hline Pasal 2 & Pasal 2 \\
\hline Pasal 3 pelaksanaan pripsip & Pasal 3 pelaksanaan prinsip \\
\hline murabahah & murabahah \\
\hline $\begin{array}{l}\text { Pasal } 4 \text { syarat realisasi pembiayaan } \\
\text { multiguna }\end{array}$ & $\begin{array}{l}\text { Pasal } 4 \quad \text { syarat realisasi kpr subsidi } \\
\text { selisih marjin }\end{array}$ \\
\hline jatuh tempo pembiayaan & Pasal 5 jatuh tempo pembiayaan \\
\hline multiguna & pembayaran kembali \\
\hline Pasal 6 pembayaran kembali & pembiayaan \\
\hline pembiayaan multiguna & Pasal 7 ta'widh dan ta'zir \\
\hline Pasal 7 denda tunggakan & pembayaran ekstra dan \\
\hline uang muka & pelunasan dipercepat \\
\hline Pasal 9 pembayaran ekstra, & Pasal 9 jaminan dan pengikatannya \\
\hline $\begin{array}{l}\text { pembayaran dimuka dan pelunasan } \\
\text { dipercepat }\end{array}$ & $\begin{array}{l}\text { Pasal } 10 \text { pernyataan kebenaran data } \\
\text { /dokumen }\end{array}$ \\
\hline Pasal 10 jaminan pengikatannya & penghunian dan pemeliharaan \\
\hline jaminan tambahan & rumah tapak/rumah susun \\
\hline Pasal 12 & Pasal 12 nasabah wanprestasi \\
\hline Pasal 13 penggunaan dan & Pasal 13 pengawasan, pemeriksaan dan \\
\hline pemeliharaan barang & tindakan terhadap barang jaminan \\
\hline nasabah wanprestasi & tanggung jawab pemilihan \\
\hline Pasal 15 pengawasan, pemeriksaan & rumah tapak/rumah susun dan \\
\hline dan tindakan terhadap jaminan & penyelesaian dokumennya \\
\hline $\begin{array}{l}\text { Pasal } 16 \text { tanggung jawab pihak - } \\
\text { pihak }\end{array}$ & $\begin{array}{l}\text { Pasal } 15 \text { penagihan seketika seluruh } \\
\text { pembiayaan dan pengosongan rumah }\end{array}$ \\
\hline $\begin{array}{l}\text { Pasal } 17 \text { penagihan seketika seluruh } \\
\text { utang murabahah }\end{array}$ & $\begin{array}{l}\text { Pasal } 16 \text { penguasaan dan penjualan } \\
\text { (eksekusi) barang jaminan }\end{array}$ \\
\hline Pasal 18 penjualan (eksekusi) & Pasal 17 pengalihan piutang \\
\hline barang jaminan & murabahah kepada pihak lain \\
\hline $\begin{array}{l}\text { Pasal } 19 \text { pengalihan piutang } \\
\text { murabahah kepada pihak lain }\end{array}$ & $\begin{array}{l}\text { Pasal } 18 \text { timbul dan berakhirnya hak - } \\
\text { hak dan kewajiban }\end{array}$ \\
\hline $\begin{array}{l}\text { Pasal } 20 \text { timbul dan berakhirnya } \\
\text { hak - hak dan kewajiban }\end{array}$ & $\begin{array}{l}\text { Pasal } 19 \text { kuasa yang tidak dapat ditarik } \\
\text { kembali }\end{array}$ \\
\hline Pasal 21 kuasa yang tidak dapat & alamat para pihak \\
\hline ditarik kembali & hukum yang berlaku \\
\hline Pasal 22 alamat pihak - pihak & lain - lain \\
\hline
\end{tabular}


Implementasi Akad Murabahah

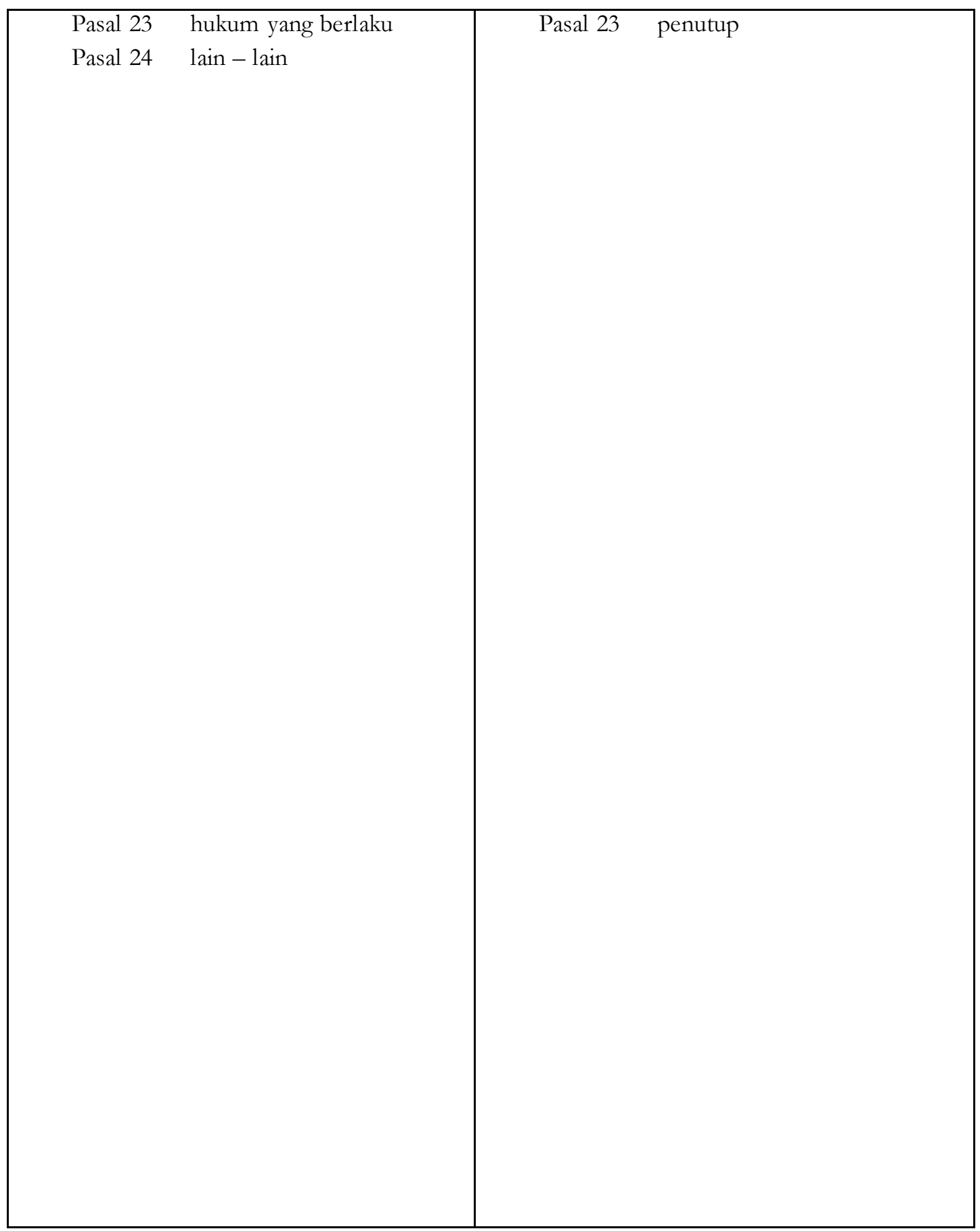

Dilihat dari struktur akad hal tersebut sudah memenuhi rukun dari akad murabahah yang dimana harus ada penjual dan pembeli yang terdapat di kedudukan pihak berakad, harga dan barang yang di bahas di isi akad pada pasal

Banco, Volume 1, Mei 2019 
1 mengenai ketentuan pokok, dan shighat yang dilakukan dengan lisan dan tulisan yang tertuang pada PK.

Pada pasal 1 juga sudah sesuai dengan syarat akad murabahah yaitu, yang pertama, menyebutkan modal kepada nasabah, yang kedua, menyebutkan margin keuntungan yang diambil sehingga bebas dari riba karena tidak memakai sistem bunga. Ketiga, menyampaikan hal berkaitan dengan pembelian hal ini dapat dilihat pada waktu akad dimana pihak bank menyebutkan bahwa rumah tersebut dibeli secara hutang.

\section{b. Akad murabahah}

Murabahah yaitu jual beli barang pada harga asal dengan tambahan keuntungan yang disepakati. Dalam murabahah, Penjual harus memberi tahu harga produk yang ia beli dan menentukan suatu tingkat keuntungan sebagai tambahannya. ${ }^{14}$ Akad murabahah merupakan akad penyaluran dana atau biasa disebut dengan akad pembiayaan, yang dilaksanakan oleh bank syariah.

Akad murabahah diatur oleh Fatwa Dewan Syariah Nasional Nomor 04/DSNMUI/IV/2000 Tentang Murabahah, pada penerapan akad murababah pada produk KPR dapat dilihat di PK pada pasal 3 yang membahas mengenai pelaksaan prinsip murabahah, pasal ini membuktikan bahwa produk KPR benar-benar menggunakan akad murabahah

Namun dalam pelaksanaan prinsip murabahah yang dilakukan pada bank BTN syariah tidak sesuai dengan prinsip yang ada pada fatwa DSN Nomor 04/DSN-MUI/IV/2000 Tentang Murabahah. Hal ini di nyatakan oleh Andi Habriantho selaku Financing Service dalam sesi wawancara ia mengatakan.

"pelaksanaan akad murabahah yang dilakukan di bank ini (bank BTN syariah) tidak sesuai dengan fatwa yang ada dikarenakan pada fatwa mengatakan Bank membeli barang yang diperlukan nasabah atas nama bank sendiri, sedangkan pada pelaksanaannya bank tidak memiliki barang tersebut pada saat akad antara bank dengan nasabah ".15

Tetapi hal ini masih belum sesuai dengan ketentuaan akad murabahah yang pada fatwa DSN Nomor 04/DSN-MUI/IV/2000 Tentang murabahah pada ketentuan umum murabahah dalam bank syariah nomor 9 yang berbunyi "Jika bank hendak mewakilkan kepada nasabah untuk membeli barang dari pihak ketiga, akad jual beli murabahah harus dilakukan setelah barang, secara prinsip, menjadi milik bank.

Jadi seharusnya dalam pelaksanaannya bank harus memilki barang tersebut terlebih dahulu sebelum melakukan akad kepada nasabah.

${ }^{14}$ Muhammad Syafi'i Antonio, Bank Syari'ah; Dari Teori ke Praktik, (Jakarta: Gema Insan, 2001), h. 101.

${ }^{15}$ Andi Habriantho, Financing Service, wawancara oleh Peneliti di Bank BTN Syariah Parepare, 2 Mei 2018. 
Tetapi menurut peneliti hal ini bukan masalah dikarenakan jika bank mengatasnamakan barang tersebut dari developer lalu memindahkan lagi ke nasabah maka hal itu akan menambah beban biaya, sehingga biaya-biaya yang dikeluarkan oleh nasabah akan banyak.

c. Margin

Margin merupakan tambahan dari harga beli pokok, yang akan menjadi Harga jual bank yang disepakati dari harga beli bank dari pemasok ditambah mark up atau margin atau keuntungan dan biaya-biaya yang timbul dari proses pembelian barang tersebut oleh bank.

Pada pelaksanaannya harga beli dari pemasok dan margin tercantum pada PK pasal 1 dan SP3 (surat persetujuan pembiayaan). Adapun margin dari KPR Platinum iB dan KPR BTN subsidi iB yaitu :

\begin{tabular}{|c|c|c|}
\hline \multicolumn{3}{|c|}{ PLATINUM } \\
\hline $\begin{array}{c}\text { JANGKA } \\
\text { WAKTU }\end{array}$ & MARGIN < 200 & MARGIN > 200 \\
JUTA & $7,1504 \%$ \\
\hline 5 TAHUN & $7,3037 \%$ & $7,3590 \%$ \\
\hline 6 TAHUN & $7,5174 \%$ & $7,5773 \%$ \\
\hline 7 TAHUN & $7,7408 \%$ & $7,8032 \%$ \\
\hline 8 TAHUN & $7,9720 \%$ & $8,0354 \%$ \\
\hline 9 TAHUN & $8,2093 \%$ & $8,2015 \%$ \\
\hline 10 TAHUN & $8,3803 \%$ & $9,1132 \%$ \\
\hline 15 TAHUN & $9,5163 \%$ & $9,9222 \%$ \\
\hline 20 TAHUN & $10,3600 \%$ & \\
\hline
\end{tabular}

Tabel 4.2 Margin KPR BTN Platinum iB

\begin{tabular}{|c|c|c|c|}
\hline \multicolumn{5}{|c|}{ SUBSIDI } \\
\hline JANGKA WAKTU & MARGIN & $\begin{array}{c}\text { JANGKA } \\
\text { WAKTU }\end{array}$ & MARGIN \\
\hline 1 TAHUN & $9,1046 \%$ & 11 TAHUN & $5,3374 \%$ \\
\hline 2 TAHUN & $7,0981 \%$ & 12 TAHUN & $5,3039 \%$ \\
\hline 3 TAHUN & $6,3939 \%$ & 13 TAHUN & $5,2757 \%$ \\
\hline 4 TAHUN & $6,0348 \%$ & 14 TAHUN & $5,2515 \%$ \\
\hline 5 TAHUN & $5,8172 \%$ & 15 TAHUN & $5,2305 \%$ \\
\hline 6 TAHUN & $5,6712 \%$ & 16 TAHUN & $5,2122 \%$ \\
\hline 7 TAHUN & $5,5665 \%$ & 17 TAHUN & $5,1961 \%$ \\
\hline 8 TAHUN & $5,4879 \%$ & 18 TAHUN & $5,1817 \%$ \\
\hline 9 TAHUN & $5,4266 \%$ & 19 TAHUN & $5,1690 \%$ \\
\hline 10 TAHUN & $5,3775 \%$ & 20 TAHUN & $5,1575 \%$ \\
\hline
\end{tabular}

Banco, Volume 1, Mei 2019 
Tabel 4.3 Margin KPR BTN Subsidi iB

Pada margin KPR platinum iB dan KPR BTN subsidi iB memiliki perbedaan.

Pada margin KPR BTN platinum iB untuk pembiayaan rumah dibawah harga 200 juta dengan jangka waktu $5-20$ Tahun berkisar 7,3037\% - 10,3600\% dan untuk pembiayaan rumah diatas harga 200 jt dengan jangka waktu $5-20$ tahun berkisar 7,1504\% - 9,9222\%. besaran margin tersebut merupakan ketentuan dari pihak bank.

Pada KPR BTN subsidi iB margin yang ditawarkan dengan jangka waktu 1- 20 tahun berkisar 9,1046\% - 5,1575\% , untuk besaran margin tersebut ditentukan sendiri oleh pemerintah yang diatur dalam permenPUPR Nomor 21/PRT/M/2016 tentang kemudahan dan atau bantuan perolehan rumah bagi masyarakat berpenghasilan rendah. Dan permenPUPR Nomor 26/PRT/M/2016 tentang perubahan atas peraturan menteri pekerjaan umum dan perumahan rakyat nomor 21/PRT/M/2016 tentang kemudahan dan atau bantuan perolehan rumah bagi masyarakat berpenghasilan rendah.

Pada hasil penelitian lapangan, untuk jangka waktu KPR subsidi yang di tawarkan bank BTN Syariah yaitu 10 tahun, 15 tahun, dan 20 Tahun.

d. Uang muka

Uang muka atau dikenal dengan DP (down payment) adalah sebagian pembayaran yang dilakukan pada awal pembelian sementara sisanya akan dibayar kemudian. Uang muka merupakan bukti atau tanda jadi atas keseriusan nasabah untuk melakukan pembiayaan.

Pada Fatwa Dewan Syariah Nasional Nomor 13/DSN-MUI/IX/2000 tentang uang muka dalam murabahah, bank diperbolehkan untuk meminta uang muka apabila kedua belah pihak bersepakat. Uang muka tersebut merupakan bentuk kehati hatian bank dalam memberikan pembiayaan kepada nasabah.

Dari hasil wawancara saudara Akbar Ansar Ashari tersebut dapat diambil kesimpulan bahwa :

1) harga rumah yang dibeli oleh bank adalah harga rumah yang telah dikurangi dengan uang muka yang dibayarkan oleh nasabah ke developer,

2) Bagi nasabah yang mengundurkan diri sebelum akad, uang muka yang dibayarkan oleh nasabah akan menjadi milik developer $100 \%$.

3) Bagi nasabah yang dibatalkan berkasnya atau penolakan pemberian pembiayaan oleh pihak bank maka uang muka yang dibayarkan nasabah akan dikembalikan $100 \%$ oleh developer.

Dilihat dari segi ketentuan fatwa dewan syariah nasional nomor 13/DSN-MUI/IX/2000 tentang uang muka dalam murabahah no 5 yang berbunyi "jika jumlah uang muka lebih besar dari kerugian, LKS harus mengembalikan kelebihannya kepada nasabah". Hal ini tidak sesuai dengan ketentuan fatwa dikarenakan pihak developer tidak mengembalikan kelebihan uang muka jika uang muka lebih besar daripada biaya yang dikeluarkan bagi nasabah yang mengundurkan diri. 
Implementasi Akad Murabahah

Hal serupa juga di ungkapkan dari saudara Dian Novianti selaku user PT. Arista Jaya yang mengatakan:

" pada saat saya membayar uang muka saya diberitahukan bahwa uang saya akan hangus apabila saya membatalkan akad dan kembali apabila berkas saya ditolak". 16

e. Diskon

Diskon adalah potongan harga yang diberikan oleh penjual kepada pembeli, diskon yang diberikan oleh penjual ada berbagai macam yaitu :

1) Diskon tunai

Diskon tunai adalah potongan harga yang diberikan kepada pembeli dari harga resmi yang tertera pada brosur harga.

2) Diskon kredit

Diskon kredit adalah potongan harga yang diberikan karena pembeli membayar utang pembelian dalam masa potongan tunai sesuai dengan syarat pembelian yang telah ditentukan.

Saudara Andi Habriantho selaku Financing Service yang mengatakan.

" Diskon yang diberikan oleh developer sebelum akad, akan di bagi 2 dengan nasabah atau diberikan semua kepada nasabah, adapun diskon yang diberikan setelah akad diskon tersebut akan jadi milik bank" . ${ }^{17}$

Fatwa Dewan Syariah Nasional Nomor 16/DSN-MUI/IX/2000 tentang diskon dalam murabahah nomor 3 yang berbunyi "Jika dalam jual beli murabahah LKS mendapat diskon dari supplier, harga sebenarnya adalah harga setelah diskon; karena itu, diskon adalah hak nasabah". Hal ini sudah sesuai dengan Fatwa Dewan Syariah Nasional Nomor 16/DSN-MUI/IX/2000 tentang diskon dalam murabahab nomor 3. Yang dimana jika diskon diberikan sebelum akad, maka menjadi hak nasabah. Pada pelaksanaannya pembahasan mengenai diskon tidak dimuat dalam PK atau diperjanjikan secara tertulis, perjanjian mengenai diskon hanya diucapkan secara lisan.

\section{f. Penjadwalan kembali (Rekstrukturisasi)}

Rekstrukturisasi kredit adalah terminologi keuangan yang banyak digunakan dalam perbankan, yang artinya adalah upaya perbaikan yang dilakukan dalam kegiatan perkreditan terhadap debitur yang mengalami kesulitan untuk memenuhi kewajibannya. ${ }^{18}$ juni 2018

${ }^{16}$ Dian Novianti, User PT. Arista Jaya, wawancara oleh Peneliti di Bank BTN Syariah Parepare, 4

17 Andi Habriantho, Financing Servive, wawancara oleh Peneliti di Bank BTN Syariah Parepare, 2 Mei 2018.

${ }^{18}$ Wikipedia, "Rekstrukturisasi kredit”.https://id.wikipedia.org/wiki/ Rekstrukturisasi kredit (2

Banco, Volume 1, Mei 2019 
Penjadwalan kembali (Rekstrukturisasi) merupakan pelayanan bank kepada nasabah yang mengalami kesulitan menunaikan kewajiban pembayaran cicilan tagihan, penjadwalan kembali bertujuan untuk memberikan keringanan kepada nasabah dalam membayar angsuran pembiayaan murabahabnya. Penjadwalan kembali mengikuti ketentuan fatwa dewan syariah nasional Nomor 48/DSN-MUI/II/205 Tentang penjadwalan kembali tagihan murabahah dengan ketentuan:

1) Tidak menambah jumlah tagihan yang tersisa

2) Pembebanan biaya dalam proses penjadwalan kembali adalah biaya riil

3) Perpanjangan masa pembayaran harus berdasarkan kesapakatan kedua belah pihak Selain fatwa, penjadwalan kembali mengikuti ketentuan SK Dir BI No 31/150/Dir/1998, tentang rekstrukturisasi kredit mengenai perpanjangan jangka waktu kredit yang merupakan pembebanan biaya riil kepada nasabah, seperti tenaga atau jasa yang dikeluarkan bank dalam rangka rescheduling. ${ }^{19}$

Adapun perhitungan penjadwalan kembali yaitu :

Sisa pokok + sisa margin berjalan + (margin JW tambahan $\mathrm{x}$ sisa pokok)

sisa jangka waktu (dalam bulan)

pada perhitungan tersebut sisa pokok tidak bertambah dalam penjadwalan kembali melainkan hanya margin yang bertambah, hal ini akan berpengaruh pada jumlah tagihan yang akan dibayarkan oleh nasabah.

Pernyataan saudara Andi Habriantho berbeda dengan Fatwa Dewan Syariah Nasional Nomor 48/DSN-MUI/II/205 Tentang penjadwalan kembali tagihan murabahab no 1 Tidak menambah jumlah tagihan yang tersisa. Namun dalam penjadwalan kembali, adanya tambahan tagihan walupun nasabah tidak menyadari dikarenakan angsuran perbulan yang dibayarkan berkurang dari sebelumnya.

g. Penyelesaian piutang bagi nasabah tidak mampu bayar

Piutang tak tertagih, menurut Keiso dan Weigand adalah kerugian pendapatan yang memerlukan melalui ayat-ayat pencatatan yang tepat dalam perkiraan harta piutang dan penurunan yang berkaitan dalam laba dan ekuitas pemegang saham, ${ }^{20}$ Secara umum suatu piutang diindikasikan sebagai piutang tak tertagih apabila telah jauh melewati tanggal jatuh tempo.

Penyelesaian piutang murabahah bagi nasabah yang tidak mampu bayar diatur dalam fatwa dewan syariah nasional nomor 47/DSN-MUI/II/2005 tentang penyelesaian piutang murabahah bagi nasabah tidak mampu membayar. Dengan ketentuan sebagai berikut :

mei 2018).

${ }^{19}$ Ahmad Ifham Solihin. Buku Pintar Ekonomi Syariah, Edisi Revisi (Jakarta: PT Gramedia, 2015), h. 717 .

${ }^{20}$ Donald E Kieso and Jerryj. Weygant, akuntansi intermediate, edisi 7 jilid I, Terj. Herman Wibowo, (Jakarta: Erlangga,2004). h. 424. 
1) Objek murabahah atau jaminan lainnya dijual oleh nasabah kepada atau melalui LKS dengan harga pasar yang disepakati.

2) Nasabah melunasi sisa utangnya kepada LKS dari hasil penjualan.

3) Apabila hasil penjualan melebihi sisa utang maka LKS mengembalikan sisanya kepada nasabah.

4) Apabila hasil penjualan lebih kecil dari sisa utang maka sisa utang tetap menjadi utang nasabah.

5) Apabila nasabah tidak mampu membayar sisa utangnya, maka LKS dapat membebaskannya.

Dapat diambil kesimpulan bahwa perlakuan barang jaminan sebagai bentuk penyelesaian piutang bagi nasabah yang sudah tidak mampu bayar sudah sesuai dengan Fatwa Dewan Syariah Nasional Nomor 47/DSN-MUI/II/2005.

h. Denda

Denda adalah bentuk hukuman yang melibatkan uang yang harus dibayarkan dalam jumlah tertentu. Jenis yang paling umum adalah denda uang yang jumlahnya tetap.

Pada Fatwa Dewan Syariah Nasional Nomor 17/DSN-MUI/IX/2000 tentang sanksi atas nasabah mampu yang menunda-nunda pembayaran. Bank diperbolehkan mengenakan denda kepada nasabah yang menunda - nunda pembayaran.Besaran denda yang dikenakan oleh bank BTN Syariah yaitu disesuaikan dengan jumlah pembiayaan di ambil. Biasanya denda yang dikenakan yaitu sebesar dibawah Rp.1000,- per hari. Untuk besaran denda yang dikenakan nasabah dapat melihat besaran denda yang dikenakan di PK (perjanjian kredit) dan SP3 (surat persetujuan pembiayaan).

i. Potongan pelunasan

Potongan pelunasan murabahah adalah pengurangan kewajiban nasabah yang diberikan oleh lembaga keuangan syariah saat nasabah melunasi kewajibannya lebih cepat dari waktu yang di tentukan. Bank syariah dapat memberikan potongan atas pelunasan sebelum jatuh tempo.

Pada bank BTN Syariah pelunasan dipercepat dibahas pad PK Dalam pasal 8 nasabah diberi hak untuk melakukan pembayaran ekstra dan pelunasan dipercepat. Syarat pelunasan dipercepat yaitu dengan pembayaran angsuran minimal 5 tahun. pada pelunasan dipercepat nasabah hanya membayar sisa pokok ditambah margin bulan berjalan dan biaya administrasi, seperti contohnya:

\section{PEMBAYARAN NORMAL \\ Plafond $\quad=$ Rp. 35.000.000,- \\ Margin $\quad=$ Rp. 29.331.050,- \\ Jangka waktu $=10$ tahun (120 bulan)}

Total yang sudah terbayarkan $=\mathrm{Rp} .32 .165 .520$

Sisa pokok $\quad=$ Rp. 17.500.040,-

Biaya administrasi $\quad=$ Rp.2.000.000,-

Margin berjalan $\quad=$ Rp. 244.425 
Gambar 4.4 Perhitungan Pembiayaan murabahah dengan potongan pelunasan, diolah dari hasil wawancara

Pada kedua perhitungan diatas dapat dilihat bahwa nasabah mendapat potongan pelunasan. Saudara Andi Habriantho selaku Financing Service mengatakan.

"Jika nasabah melakukan percepatan pelunasan maka akan diberikan potongan pelunasan namun potongan tersebut tidak diperjanjikan dalam akad". ${ }^{21}$

Dari wawancara tersebut hal ini sudah sesuai dengan Fatwa dewan syariah nasional Nomor 23/DSN-MUI/III/2002 tentang potongan pelunasan dalam murabahab yang pada ayat 1 yang mengatakan bahwa potongan yang diberikan tidak diperjanjikan di dalam akad.

Dari keseluruhan penelitian yang dilakukan peneliti dapat dilihat bahwa rukun dan syarat akad Murabahah sudah sesuai dengan prinsip murabahah, terkait dengan akad murabahah, akad tersebut belum berimplementasi dengan baik dikarenakan adanya ketentuan Fatwa Dewan Syariah Nasional Nomor 04/DSN-MUI/IV/2000 Tentang Murabahah yang tidak sesuai dengan pelaksanaanya. Diskon, penyelesaian piutang, denda, potongan pelunasan sudah sesuai dengan fatwa dewan syariah nasional, dan untuk penjadwalan kembali dan uang muka belum sesuai dengan Fatwa Dewan Syariah Nasional.

\section{Kesimpulan}

1. Mekanisme Pembiayaan KPR pada Bank BTN Syariah Parepare

Pembiayaan KPR pada Bank BTN Syariah Parepare ada dua yaitu: pertama KPR BTN Platinum iB dan KPR BTN Subsidi iB. KPR Subsidi iB merupakan pembiayaan kepemilikan rumah yang dibantu oleh pemerintah. Pemberian KPR BTN Subsidi iB diatur oleh pemerintah melalui menteri pekerjaan umum dan perumahan rakyat (menPUPR) adapun ketentuan-ketentuan KPR subsidi yaitu, untuk aturan kategori

${ }^{21}$ Andi Habriantho, Financing Servive, wawancara oleh Peneliti di Bank BTN Syariah Parepare, 2 Mei 2018. 
penerima rumah subsidi, margin dan lain-lain diatur pada permenPUPR nomor 21/PRT/M/2016 tentang kemudahan dan atau bantuan perolehan rumah bagi masyarakat berpenghasilan rendah. Dan permenPUPR nomor 26/PRT/M/2016 tentang perubahan atas peraturan menteri pekerjaan umum dan perumahan rakyat nomor 21/PRT/M/2016 tentang kemudahan dan atau bantuan perolehan rumah bagi masyarakat berpenghasilan rendah. Dan untuk penentuan harga rumah subsidi diatur padaperaturan keputusan menteri pekerjaan umum dan perumahan rakyat (permenPUPR) republik Indonesia nomor 425/KPTS/M/2015 tentang batasan harga jual rumah yang dapat diperoleh melalui kredit atau pembiayaan pemilikan rumah sejahtera. Aturan yang telah ditetapkan oleh pemerintah sudah dijalankan dengan baik oleh bank BTN syariah parepare.

\section{Implemetasi akad murabahah pada bank BTN syariah Parepare}

Pembiayaan Kepemilikan Rumah / KPR Pada Bank BTN Syariah Parepare Menggunakan Akad Murabahah. Selain Akad murabahah dalam Pembiayaan KPR juga ditemukan akad Wakalah Sebagai Akad pendamping murabahah. Pada akad murabahah terdapat unsur murabahah yang sesuai dan tidak sesuai dengan fatwa DSN MUI adapun unsur-unsur yang sesuai dengan fatwa DSN MUI yaitu Diskon,penyelesaian piutang, Denda, Potongan Pelunasan dan untuk unsur murabahah yang tidak sesuai dengan fatwa DSN MUI yaitu penjadwalan kembali dan uang muka. Jadi, Akad murabahah belum berimplemetasi dengan baik dikarenakan ada beberapa unsur akad murabahah yang tidak sesuai dengan fatwa dewan syariah nasional. 


\section{Daftar Pustaka}

\section{Buku}

Abdul Wahab, Solichin. 2008. Pengantar Analisis Kebijakan Publik. Malang: Universitas Muhammadiyah Malang Press.

Antonio, Muhammad Syafi'i. 2001. Bank Syariab; Dari Teori ke Praktik. Jakarta: Gema Insan.

Alfitra. 2014. Modus Operandi Pidana Khusus Di Luar KUHP. Jakarta: Raih Asa Sukses.

As-Shan'ani ,Imam Subulus Sala Ju₹, 3, Surabaya: Hidayah.tt.

Departemen Agama RI. 2007. Al-Qur'an dan Terjemahannya special for woman. Bandung: Syamil Qur'an.

Departemen Pendidikan Nasional. 2008. Kamus Besar Babasa Indonesia,Edisi Keempat. Jakarta: Gramedia Pustaka Utama.

Dwidjowijoto, Riant Nugroho. (2004) Kebijakan Publik: Formulasi, Implementasi, dan Evaluasi, Jakarta : PT. Elex Media Komputindo.

Hidayanti, Fitri. 2014. "Studi Analisis Akad Pembiayaan Murabahab terhadap kredit kepemilikan rumah (KPR) di Bank Muamalat Cabang Jember". Skripsi Sarjana; Jurusan Akuntansi: Jember.

Ikit. 2015. Akutansi Penghimpunan Dana Bank Syariah. Yogyakarta: Deepublish.

Irawan, Nata. 2017. Tata Kelola Pemerintahan Desa Era UU Desa. Jakarta: Yayasan Pustaka Obor Indonesia.

Ismail. 2011. Perbankan Syariah, Jakarta: Kencana Prenadamedia.

Karim, Adiwarman. 2004. Bank Islam: Analisis Fiqih dan Kenangan. Jakarta: PT RajaGrafindoPersada.

Kieso, Donald E and Jerryj Weygant. 2004. akuntansi intermediate, edisi 7 jilid I, Terj. Herman Wibowo. Jakarta: Erlangga.

Muhammad. 2005 Manajemen Bank Syariah, Edisi Revisi. Yogyakarta: UPP AMP YKPN.

Pardiansyah. 2013. "Persepsi Nasabah Terbadap Sistem Murabahah Pada Bank Syariah Cabang Kota Parepare". Skripsi Sarjana; Jurusan Syariah dan Ekonomi Islam: Parepare.

Rozalinda. 2016. Fikih Ekonomi Syariah. Jakarta : Rajawali Pers. 
Implementasi Akad Murabahah

Tahir, Ramlah. 2013. "Implementasi Akad Murabahab Terbadap Pembiayaan Take Over di Bank Muamalat Kota Parepare (Analisis Hukum Islam)". Skripsi Sarjana; Jurusan Syariah: Parepare.

Sjahdeini, Sutan Remy. 2014. Perbankan Syariah, produk - Produk dan Aspek Hukumnya. Jakarta: Prenadamedia Group.

Solihin, Ahmad Ifham. 2015. Buku Pintar Ekonomi Syariah, Edisi Revisi, Jakarta: PT Gramedia.

\section{Dokumen Lain}

Dewan Syariah Nasional-MUI. 2000. Fatwa DSN No. 04/DSNMUI/IV/2000TentangMurabahah.

. 2000. Fatwa DSN No.13/DSN-MUI/IX/2000 Tentang Uang Muka Dalam Murabahah.

. 2000. Fatwa DSN No. 16/DSN-MUI/IX/2000 Tentang Diskon Dalam Murababah.

2000. Fatwa DSN No. 17/DSN-MUI/IX/2000 Tentang Sanksi atas nasabah mampu yang menunda - nunda pembayaran.

. 2002. Fatwa DSN No. 23/DSN-MUI/III/2002 Tentang Potongan Pelunasan Dalam Murabahab.

2005. Fatwa DSN No. 46/DSN-MUI/II/2005 Tentang Potongan tagihan murabahab (khasm fi Al-murabahab).

. 2005. Fatwa DSN No. 47/DSN-MUI/II/2005 Tentang Penyelesaiaan Piutang Murabahah bagi Nasabah Tidak. Mapu Bayar.

. 2005. Fatwa DSN No. 48/DSN-MUI/II/2005 Tentang Penjadwalan Kembali Tagihan Murabahah.

2005. Fatwa DSN No. 49/DSN-MUI/II/2005 Tentang Konversi Akad Murabahah.

. 2008. Fatwa DSN No. 68/DSN-MUI/III/2008 Tentang Rabn Tasjily.

. 2012. Fatwa DSN No. 84/DSN-MUI/XII/2012 Tentang Metode Pengakuan Keuntungan Tamwil bi al-Murabahah (Pembiayaan Murababah) di Lembaga Keuangan Syariah.

Menteri Pekerjaan Umum dan Perumahan Rakyat. 2016. PermenPUPR nomor 26/PRT/M/2016 tentang perubahan atas peraturan menteri pekerjaan umum dan perumahan rakyat nomor 21/PRT/M/2016 tentang kemudahan dan / atau bantuan perolehan rumah bagi masyarakat berpenghasilan rendah. 


\section{Website}

BTN Syariah, 2017. "Profil BTN Syariah", Situs Resmi BTN Syariah. Http://www.btn.co.id/ (10 Juli 2017).

. 2017. "Produk". Situs Resmi BTN Syariah. Http://www.btn.co.id/ (10 Juli ).

Bank Indonesia. 2018. "Survei Harga Properti Residensial,Triwulan III-2017”. Situs Resmi Bank Indonesia.

Http://www.bi.go.id/ (16 Januari 2018).

Jonathan Sarwono, 2017. Metode Penelitian kuantitatif \& kualitatif. https://www. academia.edu/9832986/Buku_Metodologi_Penelitian_Kuantitatif_dan_Kualitatif_ole h_Jonathan_Sarwono (12 Juni).

Otoritas Jasa Keuangan. 2018. "Buku Standar Produk Perbankan Syariah Murabahah", Situs Resmi Otoritas Jasa Keuangan.

http://www.ojk.go.id (16 Januari 2018).

Wikipedia.2017.“KreditPemilikanRumah”.https://id.wikipedia.org/wiki/Kreditpemilikanru mah (10 Juni).

2018. “Anuitas ”.https://id.wikipedia.org/wiki/Anuitas (2 Mei).

2018. "Rekstrukturisasi kredit".https://id.wikipedia.org/wiki/Rekstrukturisasi kredit (2 Mei). 